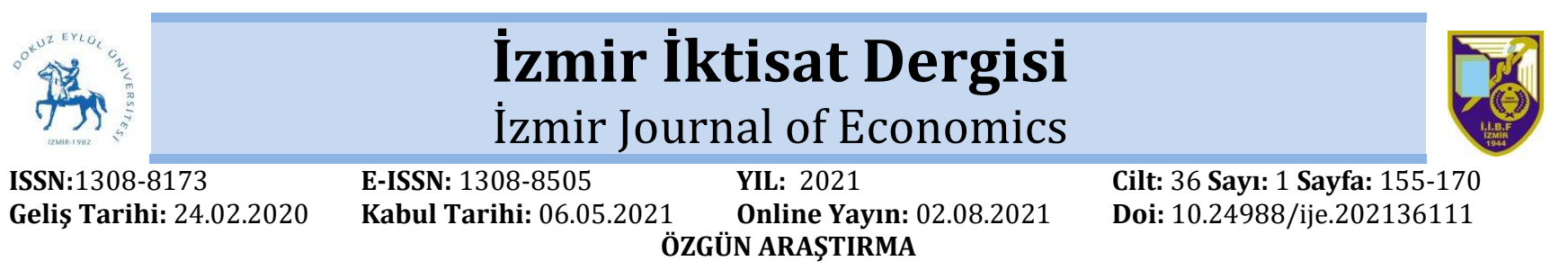

\title{
Socio-Economic Determinants of Tax Evasion: Evidence from the European Union ${ }^{1}$
}

\section{Rana DAYIOĞLU ERUL²}

\begin{abstract}
The purpose of this study is to investigate the key determinants of tax evasion across countries. Accordingly, the relationship between socio-economic determinants and tax evasion is examined by using panel data analysis. Based on the data for the European Union, the results show that economic variables have generally stronger effects than non-economic variables on tax evasion. The findings indicate that the lower the level of sound money and the higher level of social capital, economic quality and rule of law, the lower is the level of tax evasion across countries. These results may lead policy makers to design the policies by understanding the main determinants of tax evasion internationally.
\end{abstract}

Keywords: Tax evasion, cross-country analysis, sound money, social capital, economic quality, rule of law.

Jel Codes: H26, K34

\section{Vergi Kaçakçılı̆̆ının Sosyoekonomik Belirleyicileri: Avrupa Birliği Örneği Özet}

Bu çalışmanın amacı, vergi kaçakçılı̆̆ının temel belirleyicilerini araştırmaktır. Buna göre sosyo-ekonomik belirleyiciler ile vergi kaçakçılığı arasındaki ilişki; panel veri analizi ile incelenmiştir. Avrupa Birliği verilerine dayanılarakyapılan analizin sonuçları, ekonomik değişkenlerin genel olarak ekonomik olmayan değişkenlere göre vergi kaçakçılığı üzerinde daha güçlü etkileri olduğunu göstermektedir. Bulgular, güçlü paraya erişimin düşük, sosyal sermaye, ekonomik kalite ve hukuk kurallarının etkinliğinin yüksek olduğu durumlarda, vergi kaçakçılığının daha düşük olduğunu göstermiştir. Bu sonuçların, politika belirlenme sürecinin, uluslararası düzeyde vergi kaçakçılı̆̆ının temel belirleyicilerini anlayarak tasarlanması konusunda destekleyici olacağı düşünülmektedir.

Anahtar kelimeler: Vergi kaçakçılığı, ülkeler arası karşılaştırmalı analiz, güçlü paraya erişim, sosyal sermaye, ekonomik kalite, hukuk kurallarının etkinliği.

Jel Kodu: H26, K34

\section{INTRODUCTION}

Tax evasion is a major concern for European fiscal policy; because not only does it limit the capacity of countries to finance their economic and social policies; it is also fundamentally unfair, both horizontally (taxpayers with similar incomes end up paying different amounts of tax) and vertically (it reduces the redistributive power of the tax benefit system) (European Commission, 2019).
Studies that have been trying to measure underlying determinants of tax evasion have been made so far (Witte and Woodbury, 1985; Jackson and Milliron, 1986; Dubin and Wilde, 1988; Crane and Nourzad, 1990; Andreoni, Erard and Feinstein, 1998; Park and Hyun, 2003; Hasseldine and Hite, 2003; Bobek, Roberts and Sweeney, 2007; Alm, Bernasconi, Laury, Lee and Wallace, 2016; Beer, Kasper, Kirchler and Erard, 2019). In these studies, a specific country or a country group have been

ATIF ÖNERísí (APA): Dayığlu Erul, R. (2021). Socio-Economic Determinants of Tax Evasion: Evidence from the European Union. İzmir Journal of Economics. 36(1). 155-170. Doi: 10.24988/ije. 202136111

1 This study is carried out within the scope of the research support given by TUBITAK (The Scientific and Technological Research Council of Turkey).

${ }^{2}$ Asts. Prof., Ankara Hacı Bayram Veli University, Faculty of Economics and Administrative Sciences, Department of Public Finance, ANKARA, EMAIL: mrana.erul@hbv.edu.tr, ORCID: 0000-0001-9073-6430 
focused on. But in the study of Andreoni, Erard and Feinstein (1998) it is indicated that there is a need for international and cross-country comparisons on this topic because a broadening of the empirical database will improve the power of statistical tests of theoretical models and spur comparative analysis across countries (Andreoni et al., 1998: 856). Following their suggestion, many crosscountry studies have been made (RiahiBelkaoui, 2004; Richardson, 2006; Tsakumis, Curatola and Porcano, 2007; Richardson, 2008; Hofmann, Voracek, Bock and Kirchler, 2017) but there are still few cross-country studies.

The purpose of this study is to examine demographic, social and economic determinants of tax evasion and the relationship between these factors and tax evasion based on its theoretical framework. In the study, the studies of Riahi-Belkaoui (2004) and Richardson (2006) are expanded by making cross-country analysis using data of the European Union. Making cross-country analysis and classifying culturally, socially and economically similar countries into groups are important for measuring the effects on tax evasion because if these determinants are identified by empirical analysis, appropriate policy recommendations can be suggested and governments may put into practice the policies which can prevent the damages of tax evasion.

This study contributes to the literature in three ways. First, it investigates systematically many of the key demographic, social and economic determinants of tax evasion so it explores the major determinants of tax evasion across countries. As it is supposed that there are few studies including these determinants for many countries, it fills a gap in this way. Second, it includes many demographic, social and economic determinants of tax evasion together so that it can be understood which of these are more important for tax evasion across countries. Third, it also provides a summary of the determinants for future international research.

\section{MAIN DETERMINANTS OF TAX EVASION}

In this section, the main determinants of tax evasion are identified and explained by reference to the theories of tax evasion and previous studies. In this regard, different suggestions and findings take place about the determinants of tax evasion.

First of all, the first contemporary revival of the economic analysis of crime is Becker's classic article called "Crime and Punishment: An Economic Approach" in 1968. After influencing Becker's study, his study has been improved by Allingham and Sandmo and many other scientists.

Allingham and Sandmo (1972) are the first authors to examine tax evasion decision using the economic model, and the literature on the subject starts with their study and later their model is developed by many authors. The expected benefit model of Allingham and Sandmo suggests that the variables that determine tax compliance are tax control, tax penalties, risk of getting caught and punished, tax rate and income (expected benefit).

According to this theory, tax declaration decision is a decision under uncertainty; the reason for this is that failure to report one's full income to the tax authorities does not automatically provoke a reaction in the form of a penalty and in this way, the taxpayer has the choice between two main strategies (Allingham and Sandmo, 1972: 324): First, he may declare his actual income and second, he may declare less than his actual income. If he chooses the latter strategy his payoff will depend on whether or not he is investigated by the tax authorities. If he is not, he is clearly better off than under strategy; if he is, he is worse off. The choice of a strategy is therefore a non-trivial one.

In the expected benefit model the taxpayer should pay a penalty rate on the undeclared income and this assumption leads to the conclusion that when the tax rate increases there will be two opposing effects, an income 
and a substitution effect (Yitzhaki, 1974: 201). In the study of Yitzhaki, he shows that assuming that the taxpayer has an absolute risk aversion which decreases with income, it can be concluded that as the tax rate increases the income evaded decreases and in this case there is no substitution effect (Yitzhaki, 1974: 201). Thus, according to the model, Yitzhaki concludes that increasing tax rates will reduce unreported income, a prediction that contradicts general belief (Saruç, 2015: 46).

As government activities grew over the years and they required higher tax revenue, more public spending and more government regulations, tax evasion seemed to grow and to become more widespread (Tanzi, 2017: 146). In this way, tax evasion might be expected to be related to level of economic development (Mehrara and Farahani, 2016: 44). In this respect, Bethencourt and Kunze (2013) find evidence in their study that the share of evaded taxes over GDP decreases with the stage of economic development as per capita income increases. For instance, in developing countries, economic activities are conducted in a manner that does not lend itself to easy tax enforcement because in such countries, the agricultural sector is relatively large, the share of the self-sufficient economy in the total economy is high, the share of the nonmonetized economy to total gross domestic product is high and small and scattered production units are more prevalent (Richupan, 1987: 169). That's why such circumstances hinder the effectiveness of the tax enforcement mechanism and create greater temptation and opportunity for tax evasion (Richupan, 1987: 169). In line with this idea, as the development level of the countries increases, the level of tax evasion is expected to decrease.

In previous studies, income level is generally used to measure the relationship between tax evasion and economic quality or the development level of the economy. Alm,
Jackson, and McKee (1992) indicate in their results that "higher income leads to higher compliance" and Dubin, Graetz and Wilde (1987) conclude that compliance increases with per capita income. Song and Yarbrough (1978), Crane and Nourzad (1986) ${ }^{3}$, Becker, Büchner and Sleeking (1987) and Öz Yalaman and Gümüş (2013) support these findings in their studies. On the other hand, while Engel and Hines (1999) find that the tax evasion rate is positively correlated with income growth, Christie and Holzner (2006) find no evidence for high evasion by high earners and Feinstein (1991) and Richardson (2006) find no significant relationship between income and tax evasion either.

Previous studies show that tax rate is another important determinant of tax evasion. Some studies have stressed that there is a positive relationship between tax rates and tax evasion (Clotfelter, 1983; Mason and Calvin, 1984; Crane and Nourzad, 1986, 1990; Alm, Jackson and Mc Kee, 1992; Christie and Holzner, 2006; Bethencourt and Kunze, 2013). On the contrary, Feinstein (1991) has stressed in his study that higher marginal tax rates lead to reduced tax evasion by pooling data from various countries with different tax schedules. In addition, in Kamdar's study (1995), one of the most striking findings of the empirical work is that there exists an inverse relationship between tax rates and noncompliance given the prevalent belief that high marginal tax rates lead to greater noncompliance. Furthermore, Richardson (2006) finds no significant association between marginal tax rates and tax evasion.

Tax audit is a key determinant of the classical economic theory of Allingham and Sandmo. Most research find that increased audits, or the perception of increased audits, act as a deterrent to tax evasion (Witte and Woodbury, 1985; Dubin, Graetz and Wilde, 1987; Dubin and Wilde, 1988; Dubin, Graetz and Wilde, 1990; Alm, Jackson, and McKee, 1992; Alm,

\footnotetext{
3 They find that evasion has risen in absolute terms but has fallen in relative terms when real true income has risen.
} 


\section{R. DAYIOĞLU ERUL}

McClelland and Schulze, 1992; Park and Hyun, 2003; Alm et al., 2016). Beer et al. (2019) indicate that audits can have substantial deterrent or counter-deterrent effects. They find that among taxpayers who receive an additional tax assessment, reported taxable income is estimated to be higher in the first year after the audit than it would have been in the absence of the audit; in contrast, among those taxpayers who do not receive an additional tax assessment, reported taxable income is estimated to be lower the year after the audit than it would have been had the audit not taken place whereas Gemmell and Ratto (2012) find evidence in their study that audited taxpayers have reduced subsequent compliance. On the other hand, Erard (1992) examines the effects of an audit on subsequent year reporting behavior and his results, although consistent with a positive influence, are not conclusive and in addition, Zeng (2014) indicates that audit does not play a significant role in affecting people's tax reporting behaviour.

Crime and punishment are analysed in Becker's study (1968) first. According to Becker, an individual will choose to commit crime if the net expected gains from crime is greater than the net gains from not committing crime. Following Becker's study, Allingham and Sandmo (1972) examines whether the taxpayer's tax payment or non-payment status depends on the probability of being caught and not caught as a result of the audit. In addition, according to deterrence theory, an individual's perception of the certainty and severity of legal punishment should influence his decision whether to commit an illegal act (Grasmick and Green, 1980: 326).

There are many researchers who involve tax penalties/punishment in their studies. For instance, Madeo, Schepanski and Uecker (1987) indicates that penalty rates are one of the most heavily weighted variables that have effect on tax evasion, Crane and Nourzad

\footnotetext{
${ }^{4}$ See Meade, 1978: 488 for the main forms of compliance
} costs and affected parties.
(1986) point out that evasion appears to have fallen with increases the penalty rate, Savaşan and Odabaş (2005) find that there is a positive and significant relationship between nondeterrence of penalties and tax loss, Saraçoğlu (2008) has stressed that one of the most important reasons for tax evasion is insufficient tax penalties. On the contrary, Alm, Jackson, and McKee (1992) suggests that greater penalties may be largely ineffective in increasing tax compliance and Christie and Holzner (2006) find that punishment (cheat tax) variable is only significant for one of their four regression models although it is clearly expected to be significant for all. In addition, Mohdali, Isa and Yusoff (2014) show that the threat of punishment is less likely to be effective in deterring people who already have strong intentions to comply with tax laws but more likely to increase their negative intentions to comply when threat of punishment is employed as one of the tools to reduce tax noncompliance attitudes.

The term "compliance costs" is usually used to refer to all costs incurred by individuals in preparing their taxes (Alm, 1988: 61) or those costs incurred by a taxpayer or by third parties in complying with requirements of tax system (Meade, 1978: 487) ${ }^{4}$. Tax evasion derives from these compliance costs and may result maximization of profits by reducing tax liabilities (The International Tax Compact, 2010: 25). High compliance costs, that are the costs the taxpayer has to bear to gather the necessary information, fill out tax forms etc., can be an additional reason for tax evasion and avoidance (The International Tax Compact, 2010: 15). In the studies it is generally founded that compliance costs have negative effects on level of tax compliance so they cause tax evasion level to increase (Slemrod, Whiting and Shaw, 2006; Mogeni, 2014; Faridy, Copp, Freudenberg and Sarker, 2014; Barbone, Bird and Vazquez-Caro, 2012). In addition, Jenkins 
and Forlemu (1993) show that a cost effective tax system affects voluntary tax compliance.

Fishburn (1981) and Crane and Nourzad (1986) basically argue that inflation reduces the real value of taxpayers' future disposable income. Therefore, taxpayers find optimal to increase their levels of tax evasion in order to restore their future purchasing power (Caballe and Panades, 2004: 568). In this regard, the actual response of taxpayers depends on their attitudes towards risk and if risk aversion increases with real disposable income, a positive relationship between the rate of inflation and evasion may be expected (Crane and Nourzad, 1986: 219). On the contrary, when inflation is very low, fines on evaded taxes are very high in real terms and, hence, no taxpayer finds optimal to misreport his true income (Caballe and Panades, 2004: 569). In line with these opinions, Crane and Nourzad (1986) find that tax evasion in both absolute and relative terms is positively related to the inflation rate. Fishlow and Friedman (1994) show that tax compliance declines when inflation rises. In the model of Caballe and Panades (2004), they indicate that as government creates inflation, the penalty imposed on evaded taxes becomes smaller in real terms and this stimulates tax evasion.

Legal enforcement based on the rule of law provides an important foundation for the prevention of deviant forms of behavior, such as corruption and tax evasion (Schneider and Enste, 2000, 2002). In this regard, it is considered to be significantly integral to the theoretical tax evasion literature (Andreoni, Erard and Feinstein, 1998: 818). That's why, it is important to analyse the effects of legal enforcement on tax evasion. Richardson (2006) points out high correlation between legal system and tax evasion, and he indicates in another study (Richardson, 2008) that the lower legal enforcement and trust in government, the higher is the level of tax evasion across countries. Riahi-Belkaoiu (2004) finds that regardless of reputation cost and/or the legal punishment tax noncompliance trigger, a citizen might choose to comply with taxes if the laws are effective. Cross country research by Schneider and Enste $(2000,2002)$ shows that the weak and arbitrary enforcement of laws and regulations encourages tax evasion and their findings emphasize the importance of the rule of law in reducing the levels of tax evasion.

Education level is another important determinant of tax evasion. On the one hand, as higher education brings better knowledge of tax law and the rules, the possibility of making mistakes while filling the taxes is lower for higher educated people; on the other hand, as higher education is also associated with better access to information on schemes to avoid taxes, it may be also related to lower evasion but higher avoidance tendencies (Hofmann et al., 2017: 64). That's why in the literature, there is no agreement on the effects of education level on tax evasion.

For instance, some studies find evidence for negative effects. Richardson (2006) indicates that the variable of the education level represents one of the most important determinants of tax evasion across countries. This means that its association with tax evasion is negative and significant so where the general education level of taxpayers in a country is high, tax evasion can be reduced. Song and Yarbrough (1978), Witte and Woodbury (1985), Park and Hyun (2003), Bobek, Roberts and Sweeney (2007), Öz Yalaman and Gümüş (2013), Lemoine and Roland-Levy (2013) support this finding. On the contrary, Antonides and Robben (1995) indicate that a higher level of education increases the probability of tax evasion.

Gender of the taxpayers has been investigated as an important demographic determinant of tax evasion in the previous studies. These studies show that males evade a greater percentage of their taxes than females and women are more opposed to tax evasion than men (Mason and Calvin, 1978; Spicer and Becker, 1980; Hasseldine and Hite, 2003; McGee and Tyler, 2006). It may be argued that 


\section{R. DAYIOĞLU ERUL}

the obtained difference between females and males is influenced by different risk attitude functions for females and males (Torgler, 2003: 638). On the other hand, whereas Ameyaw and Dzaka (2016) conclude their study that gender has negative relationship with tax evasion, Tsakumis, Curatola and Porcano (2007) result that higher masculinity is associated with lower tax evasion levels and Richardson (2006) finds no significant associations between gender and tax evasion.

Age difference, as a sociodemographic variable, is one of the most important determinants of tax evasion. As older people differ from younger generations in lots of social and economic ways such as social values, attitudes towards the state, the need for public goods like social security and health care services and the benefit from them, being in a financial situation, they might be more compliant than younger people (Hofman et al., 2017: 64). Studies find that older people are generally more compliant than younger people for the mentioned reasons (Vogel, 1974; Witte and Woodbury, 1985; Dubin, Graetz and Wilde, 1987; Dubin and Wilde, 1988; Feinstein, 1991). On the other hand, Bobek, Hageman and Kelliher (2013) find evidence that demographic factors such as education, age, income etc. are not related to tax evasion, with the exception that those with more favourable descriptive norms tend to be more educated.

In societies with a stronger feeling of social cohesion, tax compliance is higher as well as that social norms are a crucial determinant for tax evasion (Litina and Palivos, 2014: 3). A social norm represents a pattern of behavior that is judged in a similar way by others and that therefore is sustained in part by social approval or disapproval (Alm, 2012: 14) and this social norm can be affected by the institutions that face individuals, by individuals' attitudes toward these institutions, and by individual participation in the selection of those institutions (Alm, 2012: 21). Cialdini and Trost characterize social norms as "rules and standards that are understood by members of a group, and that guide and/or constrain social behavior without the force of law" (Cialdini and Trost, 1998: 152). In this respect, social norms are generally defined as the feelings and trust level of people in the society about other citizens, institutions and government. That's why the interaction among the members of a nation, their trust and respect for one another and the support they receive from their social environment are all representative of the level of welfare (Legatum Institute, 2017: 52). This matter specifies the relationship between social norms and tax evasion.

In the previous studies, it is founded that social norms that back up tax compliance are related to higher compliance/lower tax evasion (but personal norms are more influential than general social norms) (Wenzel, 2004; Wenzel, 2007; Bobek, Roberts and Sweeney, 2007; Bobek, Hageman and Kelliher, 2013). In addition, Grasmick and Green (1980) use the variable of social disapproval in their study and they conclude that the relationship between social disapproval and tax compliance is positive.

These factors identified in this section represent a range of social and economic characteristics that are used to inform the choice of independent variables which will be included in the analysis of this study.

\section{ANALYSIS}

\subsection{Method and Sample}

The study covers the period of 2007-2018 which means that the dimension of time extends to twelve years. Since data of some variables could only be founded from the year of 2007, the period starts from this year. As the study has both horizontal section and time dimensions, the method of panel data analysis is chosen and Stata is used for the analysis.

The data included in the analysis to measure the effects of the determinants on tax evasion within the framework of the theories and literature created are analyzed through a classification of the countries for more effective 
results. In this regard, countries are classified as the European Union (EU) and 24 countries which the data can be collected for are included in the analysis ${ }^{5,6}$. That's why, the determinants of tax evasion are tried to be measured for Austria, Belgium, Bulgaria, Czech Republic, Denmark, Estonia, Finland, France, Germany, Greece, Hungary, Ireland, Italy, Lithuania, Luxemburg, Netherlands, Poland, Portugal, Romania, Slovak Republic, Slovenia, Spain, Sweden and United Kingdom.

The reason of choosing this group is that the countries share many commonalities. Despite of the fact that each nation has its own identity and ideas, they are similar in many ways. The EU countries have similar lifestyles, cultural heritages and socio and economic structure such as higher education levels, strict rules, economic growth rates etc. For these reasons, it is important to make cross-country analysis by classifying countries through their similarities to be able to measure the impacts more effectively.

\subsection{Variables}

\subsubsection{Dependent Variable}

The dependent variable in this study is represented by tax evasion (TAX). The measure of this variable depends on a country survey rating of tax evasion which is collected by the World Economic Forum and published in the Global Competitiveness Report. Although this variable includes the values of cross-country data, using one question in this study to measure tax evasion brings concerns about reliability due to measurement error. Using the data for many years mitigates against this error. As the variable is measured using the question of "tax evasion is not a threat to your economy", this variable is converted to obtain an increasing scale of tax evasion.

\footnotetext{
${ }^{5}$ As the data for selected variables are available for only a few years in some of the European countries such as Latvia and Malta, these countries are not included in the analysis.
}

\subsubsection{Independent Variables}

In the study, six economic and five social variables -in total eleven independent variables- are used in the analysis. While economic variables are economic quality, top marginal tax rate, strength of auditing and reporting standards, punishment rate, tax compliance costs and sound money, social variables are rule of law/legal enforcement, education level, female population, age and social capital. All of them are explained below.

$X_{1 i t}=E_{C O N}$ (economic quality): is one of the economic indexes created by Legatum Institute. Standard of living (measures whether citizens have access to a range of affordable goods and services, and whether economic growth is persistent with the indicators such as satisfaction with household income, satisfaction with standard of living, five-year economic growth rate), economic inclusiveness (means the degree to which everyone has the resources and opportunities to enable them to participate in society with the indicators such as absolute poverty (\% population living below $\$ 1.90$ per day), relative poverty, percentage of adult population with a bank account), antimonopoly policy (measures whether producers can compete freely in the marketplace and consumers have choice in what to purchase with the indicators such as perceptions about effectiveness of anti-monopoly policy), labour force participation (assesses the extent to which population is participating in the workforce with the indicators such as labour force participation rate (age 15+), female labour force participation rate (age 15+), unemployment rate), trade competitiveness (looks at the extent to which an economy produces a diverse range of valuable goods and services in an internationally competitive manner with a wide set of trading partners with the indicators such as export diversity index, export quality index) are effective in the

\footnotetext{
${ }^{6}$ Turkey is not included in the analysis because it is not a member of the European Union.
} 
formation of the index (Legatum Institute, 2017: 48).

$X_{2 i t}=R_{\text {ATE }}$ (top marginal tax rate): Top marginal tax rate is an indicator of economic freedom and a sub-variable of size of government. The data of this variable is collected from Fraser Institute and as the values are between 0 and 10, they are converted to values of between 0 and 100 .

$X_{3 i t}=A_{U D I T}$ it (strength of auditing and reporting standards): demonstrates the strength of audit and reporting standards, with data based on the Global Competitiveness Report prepared by the World Economic Forum. The index measures the effectiveness of audits, as well as the applicability of accounting standards. The index values are shown on a scale of 1 to 7 in the reports, 1 being the lowest and 7 the highest in terms of the power of audit and reporting standards. This scale is the product of a study with 13.877 surveys conducted in 135 countries. In this study, this variable was taken as a range with the maximum value of 7 and was converted to the maximum value of 100 to secure its compatibility with other variables.

$X_{4 i t}=P_{U N I S H}$ (punishment rate): with respect to the punishment rate, as any proper indicator could not be founded, an indicator -cheat taxacquired from the World Values Survey is used by taking the study of Christie and Holzner (2006) as an example. This variable is based on the answers (answer values change between 1 and 10 so they are transformed to the values of 1-100) to the question whether one thinks that it is justifiable to cheat on taxes. The answers of "never justifiable" is chosen for the values in the analysis. That's why it is expected that an increase in punishment rate will decrease tax evasion.

There are some missing values for several countries. Therefore, the missing values of the countries are filled with the data that belongs to another country which is similar to that country in cultural, social and economic ways. For example, Czech Republic data for Austria and Slovak Republic, Finland data for Denmark, Japan data for Korea, Spain data for Portugal,
Belgium data for Luxembourg are used in the analysis.

$X_{5 i t}=\operatorname{COST}_{\text {it }}($ tax compliance costs): is collected from Fraser Institute data and based on the World Bank's Doing Business data on the time required per year for a business to prepare, file, and pay taxes on corporate income, value added or sales taxes, and taxes on labor. As values change between 0 and 10 , they are changed to show the values of $0-100$.

$X_{6 i t}=S M O N E Y_{i t}$ (sound money): Access to sound money variable is determined by the Fraser Institute and contains sub-variables such as the size of the currency, standard deviation of inflation, inflation rate in the most recent year, or the freedom of opening bank accounts in foreign currency. The variables are on a range between 0 and 10, but are converted to a range with the maximum value of 100 for compatibility with the other variables.

$X_{7 i t}=L A W_{\text {it }}$ (rule of law/legal enforcement): is among the variables defined by the World Governance Indicators and it is expected that the increase in the variable will increase tax compliance, as well. The sub-variables accounted for in the formulation of this variable include the fairness and speed of the judicial process, civil justice, criminal justice, protection of intellectual property rights, judicial independence, trust in the judiciary and law enforcement systems, and trust in the legislative process.

$X_{\text {sit }}=E D U_{\text {it }}$ (education level): shows the level of education in the country i during the $t$ period and is taken from the Legatum Institute data. The index is prepared taking into consideration the following: access to education (wide range and accessibility of educational services, adult and young literacy rate, girls' schooling rate as compared to that of boys, Gini coefficient in the distribution of educational services), quality of education (citizen perceptions of the learning level of children, quality of primary and secondary education, rate of completion of primary education, degree of satisfaction with local schools, number of the best universities, international reputation of the universities) 
and the human capital of the workforce (skills in the workforce promoting research and development, years in secondary school per worker, higher education level per worker, the percentage of students in the secondary education age group and enrolled in technical/vocational schools) (Legatum Institute, 2017: 54). The education index is on a range of 0 to 100 , with 0 representing the lowest and 100 the highest level of education in the country. As the increase in education level improves the tax ethics and awareness of citizens, tax compliance is expected to increase in parallel with it.

$X_{\text {git }}=A G E_{\text {it }}$ (age): shows the percentage of the population which is greater than 65 years of age and the data is gathered from the World Bank.

$X_{10 i t}=$ GENDERit (female population): is defined as the percentage of the population which is female. As females tend to be less inclined to tax evasion than males, female population is chosen to measure the effects on tax evasion. Data is collected from the World Bank.

$X_{11 i t}=$ SOC $_{\text {it }}$ (social capital): is created by Legatum Institute and is among the institutional indexes. The sub-variables taken into consideration when creating the social capital index are personal and social relationships (perceptions about the possibility of making friends, the extent of expecting help of family and friends, the frequency of helping strangers, the frequency of informal financial assistance), social norms (social conformity, social commitment, trust for the police and similar institutions, the way people treat each other, the level of trust and respect), and civic participation (donations to charities, the level of volunteerism, frequency of statement of opinion at the level of public officers, and voting) (Legatum Institute, 2017: 52). The social capital index is on a range of 0 to 100 .

\subsubsection{Hypothesis}

Following from the above theories and literature and the definitions of the determinants, it is hypothesized that:
H1. All else equal, there is a significant negative association between economic quality and tax evasion in a country.

H2. All else equal, there is a significant positive association between marginal tax rates and tax evasion in a country.

H3. All else equal, there is a significant negative association between audit and tax evasion in a country.

H4. All else equal, there is a significant negative association between punishment rate and tax evasion in a country.

H5. All else equal, there is a significant positive association between tax compliance costs and tax evasion in a country.

H6. All else equal, there is a significant positive association between sound money and tax evasion in a country.

H7. All else equal, there is a significant negative association between rule of law and tax evasion in a country.

H8. All else equal, there is a significant negative association between level of education and tax evasion in a country.

H9. All else equal, there is a significant negative association between older taxpayers and tax evasion in a country.

H10. All else equal, there is a significant negative association between female taxpayers and tax evasion in a country.

H11. All else equal, there is a significant negative association between social capital and tax evasion in a country.

\subsubsection{Model of the Analysis}

To examine the economic, social and demographic variables of tax evasion, the following model is estimated:

$\mathrm{TAX}_{i t}=\beta_{0}+\beta_{1} \mathrm{ECON}_{i t}+\beta_{2} \mathrm{RATE}_{i t}+\beta_{3} \mathrm{AUDIT}_{i t}+$ $\beta_{4} \mathrm{PUNISH}_{i t}+\beta_{5} \mathrm{COST}_{i t}+\beta_{6} \mathrm{SMONEY}_{i t}+\beta_{7} L A W_{i t}$ $+\beta_{8} \mathrm{EDU}_{i t}+\beta_{9} \mathrm{AGE}_{i t}+\beta_{10} \mathrm{GENDER}_{i t}+\beta_{11} \mathrm{SOC}_{i t}+$ $u_{\text {it }}$ 
where $\mathrm{TAX}_{i t}$ is the tax evasion level for country $i$ in $t$ time period, RATE $i t$ top marginal tax rate for country $i$ in $t$ period, AUDIT it strength of auditing and reporting standards for country $i$ in $t$ period, $\mathrm{PUNISH}_{i t}$ punishment rate for country $i$ in $t$ period, COST $i t$ tax compliance costs for country $i$ in $t$ period, SMONEY it sound money for country $i$ in $t$ period, $L A W_{i t}$ rule of law/legal enforcement for country $i$ in $t$ period, EDU ${ }_{i t}$ level of education for country $i$ in $t$ period, $\mathrm{AGE}_{i t}$ the percentage of the population greater than 65 for country $i$ in $t$ period, GENDER $i t$ the percentage of the population that is female for country $i$ in $t$ period, SOC $i t$ social capital for country $i$ in $t$ period and $u_{i t}$ is the error term for country $i$ in $t$ period.

\section{EMPIRICAL RESULTS OF THE ANALYSIS}

Table 1 reports descriptive statistics of the variables which are used in the study. These statistics are shown for the selected sample of the EU countries in Table 1.

Table 1: Descriptive statistics

\begin{tabular}{lccccc}
\hline Variable & Number & Mean & S.D. & Min. & Max. \\
\hline TAX & 288 & 56.84 & 16.25 & 26.74 & 91.42 \\
ECON & 288 & 70.97 & 6.77 & 53.69 & 82.24 \\
RATE & 288 & 43.45 & 19.68 & 10 & 85 \\
AUDIT & 288 & 75.27 & 9.58 & 52.85 & 94.28 \\
PUNISH & 288 & 53.79 & 9.72 & 39.6 & 72.2 \\
COST & 288 & 22.23 & 12.99 & 5.60 & 100 \\
SMONEY & 288 & 94.78 & 2.74 & 79.78 & 98.64 \\
LAW & 288 & 82.94 & 13.82 & 51.92 & 100 \\
EDU & 288 & 77.75 & 4.93 & 68.20 & 86.67 \\
AGE & 288 & 17.52 & 2.44 & 10.65 & 22.75 \\
GENDER & 288 & 51.23 & .951 & 49.53 & 54.01 \\
SOC & 288 & 54.88 & 7.64 & 36.14 & 67.10 \\
\hline
\end{tabular}

Table 2 summarizes the results of the panel data analysis for the model. To take the results of the analysis, two-way fixed effects model is used. Furthermore, it is applied resistant estimators because of the existence of the problems of variance, autocorrelation, or

\footnotetext{
7 For the test results, see Appendix. In order to test the variance, the modified Wald test is tested with the fixed effects model; the autocorrelation is tested using the Bhargava, Franzini, and Narendranathan's Durbin
}

interdivisional correlation ${ }^{7}$ and consequently, Table 2 shows the final results after all.

According to the results, it can be seen that the explanatory power of the model is $64 \%$. This is an indication that the explanatory power of the variables is high enough for the analysis and the variables are strong enough to explain the model.

Concerning the significance of the coefficients for the independent variables used in the model, results represented in Table 2 show that SMONEY is the most important determinant of tax evasion. The relationship between SMONEY and TAX is significant and positive, therefore, H6 is supported by the results. For the evaluation of this variable, taking into consideration the Tanzi effect is also important because a high inflation rate creates a Tanzi effect and increases tax evasion is yet another factor in the results obtained. In addition, as one of the sub-variables of sound money is the freedom of opening bank accounts in foreign currency, this is thought to be due to the increase in tax planning techniques. As a matter of fact, the increasingly easy access to tax havens and shifting investments may cause an increasing effect on tax evasion.

SOC is the second most important determinant of tax evasion for the EU. The relationship between SOC and TAX is significant and negative, consequently, $\mathrm{H} 11$ is confirmed by the results. This finding is thought to be due to the high sense of the citizens in these countries about belonging to the country and the society, trust in the government and other people and feeling safe in the country. When social capital increases, this can decrease tax evasion and this means that it can be suggested to governments as a policy to decrease the level of tax evasion.

On the other hand, ECON is another important variable for tax evasion. It also has negative and significant association with TAX as expected

Watson and Baltagi-Wu's Local Best Invariant Tests; and the Pesaran test is used to test the interdivisional correlation. 
and this result supports $\mathrm{H} 1$. Because more developed economies bring decreasing levels of tax evasion, therefore, the higher economic quality level, the lower tax evasion. That's why, attempts and policies to increase economic development of a country can definitely be an effective policy to prevent from tax evasion.

Table 2: Final results

\begin{tabular}{|c|c|c|c|}
\hline Variable & Coef. & Stand. er. & t stat. \\
\hline ECON & $\begin{array}{l}-.5851^{*} \\
(0.082)\end{array}$ & .3360 & -1.74 \\
\hline RATE & $\begin{array}{c}-2058^{* * *} \\
(0.000)\end{array}$ & .0278 & -7.40 \\
\hline AUDIT & $\begin{array}{c}.0346 \\
(0.757)\end{array}$ & .1120 & 0.31 \\
\hline PUNISH & $\begin{array}{c}.0272 \\
(0.799)\end{array}$ & .1069 & 0.25 \\
\hline COST & $\begin{array}{l}.1340^{* *} \\
(0.027)\end{array}$ & .0604 & -2.22 \\
\hline SMONEY & $\begin{array}{l}.6569 * * \\
(0.011)\end{array}$ & .2575 & 2.55 \\
\hline LAW & $\begin{array}{c}-.5524^{* * *} \\
(0.000)\end{array}$ & .1362 & -4.06 \\
\hline EDU & $\begin{array}{c}-.2582^{* *} \\
(0.018)\end{array}$ & 1091 & -2.37 \\
\hline AGE & $\begin{array}{c}.3726 \\
(0.268)\end{array}$ & .3367 & 1.11 \\
\hline GENDER & $\begin{array}{c}.4408 \\
(0.537)\end{array}$ & .7135 & 0.62 \\
\hline SOC & $\begin{array}{c}-.6025^{* * *} \\
(0.000)\end{array}$ & .1713 & -3.52 \\
\hline Fixed & $\begin{array}{c}102.0802^{* *} \\
(0.031)\end{array}$ & 47.4593 & 2.15 \\
\hline $\mathrm{R}^{2}$ & 0.6436 & & \\
\hline
\end{tabular}

Note: ${ }^{* * *}, * *$ and $*$ indicate that the null hypothesis is rejected in $1 \%, 5 \%$ and $10 \%$, respectively.

The next most important determinant across countries is LAW. Its association with TAX is negative and significant, consequently, H7 is confirmed by this finding. As this variable shows the power of authority and how strong the rules in a country are, these results are the expected. Additionally, the impact of the variable on tax evasion is high and positive in comparison to other variables because these countries have the highest power level of the government, the authorities and the rule of law as a structure of the society.
For EDU, which is a social variable, it has a negative relationship with TAX as expected and H8 is supported. This can be a policy that where the education level in a country gets high, tax evasion can be reduced. This finding is especially important for developed countries like EU countries due to the fact that they already have the highest education level comparing to other countries. As the citizens in these countries have the highest education levels in the world, they may choose to use their high level of education to be compliant, rather than using their knowledge to take advantage of the legal gaps for tax evasion or ship their investments to other countries that have lower tax rates or audits.

RATE and COST are the last significant determinants of tax evasion. Concerning RATE, as marginal tax rate has a significant and negative effect on tax evasion, $\mathrm{H} 2$ is not supported by the results. Therefore, this finding about the impact of tax rate contributes to the study of Feinstein (1991). For COST, its association with TAX is positive, so $\mathrm{H} 5$ is supported. This is, because when tax compliance costs get higher, this increases tax evasion because of the due to increased difficulty level of transactions about taxation.

Demographic variables which are AGE and GENDER are not significant across countries, in other words, there is no relationship between these variables and tax evasion. This finding reduces the strength of the impact of social variables on tax evasion. In addition, for the other economic determinants of tax evasion, which are AUDIT and PUNISH, no significant association is found with tax evasion. As a result, $\mathrm{H} 3, \mathrm{H} 4, \mathrm{H} 9$ and $\mathrm{H} 10$ are not supported by the findings.

Finally, all results show that economic variables have a higher impact on tax evasion in comparison to non-economic variables. These findings show that creating mixed models by combining demographic, social and economic variables together can provide more effective results to indicate which variables should be used for preventing the damages of tax evasion 


\section{R. DAYIOĞLU ERUL}

for different countries. The findings support Cummings, Martinez-Vazquez and McKee (2001)'s opinion which is that combining economic and non-economic determinants of tax evasion leads to a better understanding of the subject.

\section{CONCLUSION AND FUTURE RESEARCH}

Tax evasion is an increasingly salient policy concern for all governments. While many of the studies on tax evasion are made on a country basis, there is a gap in terms of cross-country studies. In this regard, this study aims to fill this gap by measuring the determinants of tax evasion through cross-country analysis, to extend the studies of Riahi-Belkaoui (2004) and Richardson (2006) and to find out the strongest determinants of tax evasion for governments to seek how to reduce tax evasion.

Panel data analysis show that economic variables are stronger than non-economic variables for tax evasion. Taking into consideration demographic, social and economic variables together provide the chance to evaluate all of them for investigating the stronger ones. Access to sound money is found to be the most important determinant of tax evasion for the EU countries and its association with tax evasion is positive. In addition, social capital, economic quality and rule of law are the next strongest variables to reduce the level of tax evasion. As these variables increase, they lead tax evasion to decrease. On the other hand, no association is found between demographic variables and tax evasion, so focusing on demographic variables rather than economic variables is not a good policy for lower tax evasion levels. That's why, countries may choose to differ their policies to reduce tax evasion depending on these implications. These results may allow governments to design their policies by understanding the main determinant of tax evasion internationally and lead to increase tax revenues.

This study has several limitations. First, the lack of data means that is not possible to include many years to the analysis. For instance, data of tax evasion is collected for the years between 1995 and 2018, however, as data of

independent variables cannot be obtained for all these years, fewer years' data is included in the analysis. Second, the sample of 24 countries is relatively small, but this is a general problem of cross-country analysis and data of tax evasion is not available for many countries. Third, measuring tax evasion by survey data may lead to concern about its reliability but as many years' data as possible are used to cope with this problem.

As it is indicated that economic variables appear to be more important than noneconomic variables for tax evasion, future research will focus on economic variables by using extended data of country sample and years. In addition, it is found that social capital is one of most important determinants of tax evasion for the EU. When social capital increases, tax evasion decreases. More studies are needed to evaluate the impact of social capital or social norms on tax evasion by deepening this variable and it is planned to measure its effects by using surveys for a specific country.

\section{REFERENCES}

Allingham, M. G. and Sandmo, A. (1972). Income Tax Evasion: A Theoretical Analysis. Journal of Public Economics, 1, 323-338.

Alm, J. (1988). Compliance Costs and The Tax Avoidance-Tax Evasion Decision. Public Finance Quarterly, 16(1), 31-66.
Alm, J. (2012). Measuring, explaining, and controlling tax evasion: Lessons from theory, experiments, and field studies. Tulane University Tulane Economics Working Paper Series, Working Paper 1213. Retrieved from http://repec.tulane.edu/RePEc/pdf/tul1213.p df, 27.12.2019. 
Alm, J., Bernasconi, M., Laury, S., Lee, D. J. and Wallace, S. (February 2016). Culture, Compliance, and Confidentiality: A Study of Taxpayer Behavior in the United States and Italy. University Ca' Foscari of Venice, Dept. of Economics Research Paper Series, No. 36, 1-35.

Alm, J., Jackson B. R. and Mckee, M. (1992). Estimating the Determinants of Taxpayer Compliance with Experimental Data. National Tax Journal, 45(1), 107-114.

Alm, J., McClelland, G. H. and Schulze, W. D. (1992). Why Do People Pay Taxes? Journal of Public Economics, 48(1), 21-48.

Ameyaw, B. and Dzaka, D. (2016). Determinants of Tax Evasion: Evidence from Ghana. Modern Economy, 7, 1653-1664.

Andreoni, J., Erard, B. and Feinstein, J. (1998). Tax compliance. Journal of Economic Literature, 36, 818-860.

Antonides, G. and Robben, H. S. J. (1995). True Positives and False Alarms in the Detection of Tax Evasion. Journal of Economic Psychology, 16, 617-640.

Barbone, L., Bird, R. M. and Vazquez-Caro, J. (2012). The Costs of VAT: A Review of the Literature. International Center for Public Policy Working Paper, 12-22 April 2012.

Becker, G. S. (March-April 1968). Crime and Punishment: An Economic Approach. The Journal of Political Economy, 76(2), 169-217.

Becker, W., Büchner, H. J. and Sleeking, S. (1987). The Impact of Public Transfer Expenditures on Tax Evasion: An experimental approach. Journal of Public Economics, 34(2), 243-252.

Beer, S., Kasper, M., Kirchler, E. and Erard, B. (2019). Do Audits Deter or Provoke Future Tax Noncompliance? Evidence on Self-employed Taxpayers. IMF Working Paper, WP/19/223.

Bethencourt, C. and Kunze, L. (2013). Tax Evasion, Social Norms and Economic Growth. MPRA (Munich Personal RePEc Archive). MPRA Paper No. 48427. Retrieved from https://mpra.ub.uni-muenchen.de/48427/, 25.12.2019.

Bobek, D. D., Hageman, A. M. and Kelliher, C. F. (2013). Analyzing the Role of Social Norms in Tax Compliance Behavior. Journal of Business Ethics, 115, 451-468.

Bobek, D. D., Roberts, R. W. and Sweeney, J. T. (2007). The Social Norms of Tax Compliance: Evidence from Australia, Singapore, and the United States. Journal of Business Ethics, 74, 49-64.

Caballe, J. and Panades, J. (2004). Inflation, Tax Evasion, and the Distribution of Consumption. Journal of Macroeconomics, 26(4), 567-595.

Christie, E. and Holzner, M. (2006). What Explains Tax Evasion? An Empirical Assessment based on European Data. The Vienna Institute for International Economic Studies (WIIW) Working Paper, No. 40.

Clotfelter, C. T. (1983). Tax evasion and tax rates: An analysis of individual returns. The Review of Economics and Statistics, 65, 363373.

Crane, S. E. and Nourzad, F. 1986. Inflation and Tax Evasion: An Empirical Analysis. The Review of Economics and Statistics, 68(2), 217-223.

Crane, S. E. and Nourzad, F. (1990). Tax Rates and Tax Evasion: Evidence from California Amnesty Data. National Tax Journal, 43(2), 189-199.

Cummings, R. G., Martinez-Vazquez, J. and McKee, M. (2001). Cross Cultural Comparisons of Tax Compliance Behavior. Working Paper No. 01-3, International Studies Program. Atlanta, Georgia: Andrew Young School of Policy Studies, Georgia State University.

Dubin, J. A., Graetz, M. J. and Wilde, L. L. (1987). Are We A Nation of Tax Cheaters? New Econometric Evidence on Tax Compliance. American Economic Review, AEA Papers and Proceedings, 77(2), 240-245.

Dubin, J. A. and Wilde, L. L. (1988). An empirical analysis of federal income tax auditing and compliance. National Tax Journal, 41, 61-74. 


\section{R. DAYIOĞLU ERUL}

Dubin, J. A., Graetz, M. J. and Wilde, L. L. (1990). The Effect of Audit Rates on the Federal Individual Income Tax. National Tax Journal, 43(4), 395-409.

Engel, E. M. R. A. and Hines, J. R. (1999). Understanding Tax Evasion Dynamics. National Bureau of Economic Research, Working Paper 6903.

Erard, B. (1992). The Influence of Tax Audits on Reporting Behaviour. In J. Slemrod (Ed.), Why People Pay Taxes: Tax Compliance and Enforcement (pp. 95-114). Ann Arbor: University of Michigan Press.

European Commission (2019). The fiscal and social cost of tax evasion: the impact of underreporting of income by the selfemployed. Retrieved from https://ec.europa.eu/jrc/sites/jrcsh/files/fair ness_pb2019_taxevasion.pdf, 26.12.2019.

Faridy, N., Copp, R., Freudenberg, B. and Sarker, T. (2014). Complexity, Compliance Costs and Non-Compliance with VAT by Small and Medium Enterprises (SMEs) in Bangladesh: Is there a Relationship?. Australian Tax Forum. Retrieved from

http://hdl.handle.net/10072/63522, 05.01.2020.

Feinstein, J. S. (1991). An Econometric Analysis of Income Tax Evasion and Its Detection. RAND Journal of Economics, 22(1), 14-35.

Fishburn, G. (1981). Tax Evasion and Inflation. Australian Economic Papers, 20, 325-332.

Fishlow, A. and Friedman, J. (1994). Tax evasion, Inflation and Stabilization. Journal of Development Economics, 43(1), 105-123.

Gemmell, N. and Ratto, M. (2012). Behavioral Responses to Taxpayer Audits: Evidence from Random Taxpayer Inquiries. National Tax Journal, 65(1), 33-58.

Grasmick, H. G. and Green, D. E. (1980). Legal Punishment, Social Disapproval and Internalization as Inhibitors of Illegal Behavior. Journal of Criminal Law and Criminology, 71(3), 325-335.
Hasseldine, J. and Hite, P. A. (2003). Framing, Gender and Tax Compliance. Journal of Economic Psychology, 24, 517-533.

Hofmann, E., Voracek, M., Bock, C. and Kirchler, E. (2017). Tax Compliance Across Sociodemographic Categories: Meta-Analyses of Survey Studies in 111 Countries. Journal of Economic Psychology, 62, 63-71.

Jackson, B. R. and Milliron, V. C. (1986). Tax Compliance Research: Findings, Problems and Prospects. Journal of Accounting Literature, 5, 125-165.

Jenkins, G. P. and Forlemu, E. N. (1993). Enhancing Voluntary Compliance by Reducing Compliance Costs: A Taxpayer Service Approach. Tax Administration Review, 12, 1123.

Kamdar, N. (1995). Information Reporting and Tax Compliance: An Investigation Using Individual TCMP Data. Atlantic Economic Journal, 23(4), 278-292.

Legatum Institute (2017). The Legatum Prosperity Index 2017 (Eleventh Edition).

Lemoine, J. E. and Roland-Levy, C. (2013). Are Taxpayers, Who Pay Their Taxes, All Cooperative Citizens?. Citizenship Teaching\&Learning, 8(2), 195-213.

Litina, A. and Palivos, T. (2014). Corruption, Tax Evasion and Social Values. MPRA (Munich Personal RePEc Archive). MPRA Paper No. 58438. Retrieved from https://mpra.ub.unimuenchen.de/58438/, 28.12.2019.

Madeo, S. A., Schepanski, A. and Uecker, W. C. (1987). Modeling Judgments of Taxpayer Compliance. The Accounting Review, 62(2), 323-342.

Mason, R. and Calvin, L. (1978). A study of admitted income tax evasion. Law and Society Review, 12, 73-89.

Mason, R. and Calvin, L. D. (1984). Public Confidence and Admitted Tax Evasion. National Tax Journal, XXXVII, 489-496.

McGee, R. W. and Tyler M. (2006). Tax Evasion and Ethics: A Demographic Study of 33 
Countries. Andreas School of Business Working Paper.

Meade, J. E. (1978). The Structure and Reform of Direct Taxation. London: The Institute for Fiscal Studies (IFC).

Mehrara, M. and Farahani, Y. G. (2016). The study of the effects of tax evasion and tax revenues on economic stabilities in OECD countries. World Scientific News, 33, 43-55.

Mogeni, E. D. (2014). The Effects of Compliance Cost on Tax Compliance of Companies Listed at the Nairobi Securities Exchange. A Research Project Submitted to School of Business, University Of Nairobi in Partial Fulfilment of the Award.

Mohdali, R., Isa, K. and Yusoff, S. H. (2014). The impact of threat of punishment on tax compliance and noncompliance attitudes in Malaysia. Procedia-Social and Behavioral Sciences, 164, 291-297.

Öz Yalaman, G. and Gümüş, E. (2013). Determinants of Tax Evasion Behavior: Empirical Evidence from Survey Data. International Business and Management, 6(2), 15-23.

Park, C. G. and Hyun, J. K. (2003). Examining The Determinants of Tax Compliance by Experimental Data: A Case of Korea. Journal of Policy Modeling, 25, 673-684.

Riahi-Belkaoiu, A. (2004). Relationship Between Tax Compliance Internationally and Selected Determinants of Tax Morale. Journal of International Accounting, Auditing and Taxation, 13, 135-143.

Richardson, G. (2006). Determinants of Tax Evasion: A Cross-Country Investigation. Journal of International Accounting, Auditing and Taxation, 15, 150-169.

Richardson, G. (2008). The relationship between culture and tax evasion across countries: Additional evidence and extensions. Journal of International Accounting, Auditing and Taxation, 17, 67-78.
Richupan, S. (1987). Determinants of Income Tax Evasion: Role of Tax Rates, Shape of Tax Schedules, and Other Factors. In V. P. Gandhi (Ed.), Supply-Side Tax Policy-Its Relevance to Developing Countries (pp. 140-174). Washington, D. C.: International Monetary Fund.

Saraçoğlu, F. (2008). Evaluation of the Effects of Age-Gender-Marital Status and Education on Attitude Against Taxes within the Framework of the Survey Results. Karamanoğlu Mehmetbey University Journal of Economic and Administrative Sciences Faculty, 15, 16-34.

Saruç, N. T. (2015). Tax Compliance: Theory and Politics. Ankara: Seçkin Publishing.

Savaşan, F. and Odabaş, H. (2005). An Empirical Study on Causes of Tax Loss and Tax Evasion in Turkey. The Journal of Social Economic Research, 10, 1-28.

Schneider, F. and Enste, D. (2000). Shadow economies around the world: Size, causes and consequences. IMF Working Paper WP/00/26, 1-56.

Schneider, F. and Enste, D. (2002). Hiding in the shadows: The growth of the shadow economy. Economic Issues, 30, 1-12.

Slemrod, J., Whiting, J. and Shaw, J. (2006). Tax Implementation Issues in the United Kingdom. The Institute for Fiscal Studies Working Draft, 24th August 2006.

Song, Y. and Yarbrough, T. E. (1978). Tax Ethics and Taxpayer Attitudes: A Survey. Public Administration Review, 38(5), 442-452.

Spicer, M. W. and Becker, L. A. (1980). Fiscal Inequity and Tax Evasion: An Experimental Approach. National Tax Journal, 33(2), 171175.

Tanzi, V. (2017). Corruption, Complexity and Tax Evasion. eJournal of Tax Research, 15(2), 144-160.

The International Tax Compact (December 2010). Addressing Tax Evasion and Tax Avoidance in Developing Countries. Retrieved from 
https://www.taxcompact.net/sites/default/fil es/resources/2010-12-ITC-Addressing-TaxEvasion-and-Avoidance.pdf, 05.01.2020.

Torgler, B. (2003). Tax Morale: Theory and Empirical Analysis of Tax Compliance. Dissertation der Universität Basel zurErlangung der Würdeeines Doktors der Staatswissenschaften, Basel.

Tsakumis, G. T., Curatola, A. P. and Porcano, T. M. (2007). The Relation Between National Cultural Dimensions and Tax Evasion. Journal of International Accounting, Auditing and Taxation, 16, 131-147.

Vogel, J. (1974). Taxation and Public Opinion in Sweden: An Interpretation of Recent Survey Data. National Tax Journal, XXVII(4), 499-513.

Wenzel, M. (2004). An Analysis of Norm Processes in Tax Compliance. Journal of Economic Psychology, 25, 213-228.

Wenzel, M. (2007). The Multiplicity of Taxpayer Identities and their Implications for Tax Ethics. Law \& Policy, 26(1), 31-50.
Witte, A. D. and Woodbury, D. F. (1985). The effect of Tax Laws and Tax Administration on Tax Compliance: The Case of the U.S. Individual Income Tax. National Tax Journal, 38, 1-13.

Yitzhaki, S. (1974). A Note on Income Tax Evasion: A Theoretical Analysis. Journal of Public Economics, 3, 201-202.

Zeng, T. (2014). What Affects Tax Compliance Behaviour: A Survey Study. International Proceedings of Economics Development and Research (IPEDR), 69, 25-28.

Appendix. Results of Heteroscedasticity, Autocorrelation, Interdivisional Correlation

\begin{tabular}{|l|l|}
\hline Heteroscedasticity & $\begin{array}{l}\text { chi2 }(24)=253.59 \\
\text { Prob }>\text { chi2 }=0.0000\end{array}$ \\
\hline \multirow{4}{*}{ Autocorrelation } & $\begin{array}{l}\text { modified Bhargava et al. } \\
\text { Durbin-Watson }=1.2429094 \\
\text { Baltagi-Wu LBI }=1.4004594\end{array}$ \\
\hline $\begin{array}{l}\text { Interdivisional } \\
\text { correlation }\end{array}$ & $\begin{array}{l}\text { Pesaran's test of cross } \\
\text { sectional independence } \\
15.800, \text { Pr }=0.0000\end{array}$ \\
\hline
\end{tabular}

